\title{
Medulloblastoma : A Common Pediatric Malignancy
}

ISSN: 2576-9200

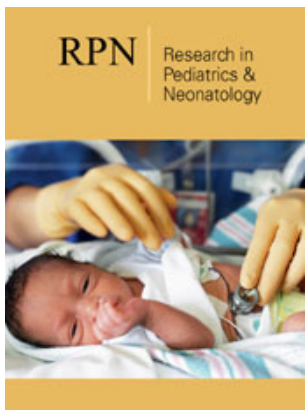

*Corresponding author: Behzad Saberi, Medical Research, Esfahan, Iran

Submission: 戝 October 10, 2020

Published: 址 November 09, 2020

Volume 5 - Issue 1

How to cite this article: Behzad Saberi Medulloblastoma : A Common Pediatric Malignancy. Research in Pediatrics \& Neonatology. 5(1). RPN. 000603. 2020. DOI: $10.31031 /$ RPN.2020.05.000603

Copyright $(\subseteq$ Behzad Saberi. This article is distributed under the terms of the Creative Commons Attribution 4.0 International License, which permits unrestricted use and redistribution provided that the original author and source are credited.

\author{
Behzad Saberi ${ }^{1 *}$ \\ ${ }^{1}$ Medical Research, Esfahan, Iran
}

\section{Introduction}

Medulloblastoma arises from the fourth ventricle's roof of the brain. It is the most common primitive neuroectodermal tumor and is one of the most common pediatric malignancies. It's male to female ratio is about two to one. Arising from the forth ventricle's roof, causes tumor to develop hydrocephalus. Complete resection of the tumor in case of presence of the brainstem invasions is impossible. At the time of diagnosis, investigation for metastasis should be done since about ten to thirty-five percent of the cases have shown some degrees of metastasis once they have been diagnosed [1-4]. Medulloblastoma comprises about fifteen to twenty percent of the intracranial tumors in the pediatric groups. The first decade of life is the peak time for medulloblastoma appearance.

Surgical debulking of the tumor and radiation therapy make the treatment strategy for medulloblastoma. In the surgical approach to debulk the tumor, it may be necessary to remove the posterior arch of the atlas and also to open the foramen magnum. About thirty to forty percent of the cases may require shunts which would be permanently placed [5-8]. Craniospinal axis radiation with thirty-five to forty Gy radiation plus tumor bed fifteen Gy boost up, make the radiation treatment strategy for the tumor. Vincristine and lomustine can be used for chemotherapy although there is no specific regimen to use for medulloblastoma chemotherapy.

Based on the modified chang classification for medulloblastoma, tumors with less than three centimeters in their maximal diameter which are limited to the midline of the vermis and fourth ventricle's roof or cerebellar hemisphere with no metastasis, will be graded as T1M0 and ones with equal or more than three centimeters in their maximal diameter with sylvius aqueduct extension and third ventricle or midbrain or magendie foramen involvement and extraneural metastasis, will be graded as T4M4.

Prognosis of medulloblastoma depends on some factors like the histology, patient's age, the extension of disease and the extension of the surgical resection of the tumor [9-12]. Showing glial, neuronal, ependymal differentiation in histological studies, showing more than M1 grade in the disease extension (gross nodular seeding in cerebral, cerebellar and spinal subarachnoid spaces or in the third or lateral ventricles and extraneural metastasis), subtotal resection of the tumor by surgery and having less than three years of age, are the factors which make the medulloblastoma prognosis poor.

\section{References}

1. Smoll NR, Drummond KJ (2012) The incidence of medulloblastomas and primitive neurectodermal tumours in adults and children. J Clin Neurosci 19(11): 1541-1544.

2. Rutkowski S, Hoff KV, Emser A, Zwiener I, Pietsch T, et al. (2010) Survival and prognostic factors of early childhood medulloblastoma: An international meta-analysis. J Clin Oncol 28(33): 4961-4968.

3. Eberhart CG, Kepner JL, Goldthwaite PT, Kun EL, Duffner PK, et al. (2002) Histopathologic grading of medulloblastomas: A Pediatric Oncology Group study. Cancer 94(2): 552-560.

4. Louis DN, Ohgaki H, Wiestler OD, Cavenee WK, Burger PC, et al. (2007) The 2007 WHO classification of tumours of the central nervous system. Acta Neuropathol 114(2): 97-109. 
5. Packer RJ, Sutton LN, Angio GD, Evans AE, Schut L, et al. (1985) Management of children with primitive neuroectodermal tumors of the posterior fossa/medulloblastoma. Pediatr Neurosci 12(4-5): 272-282.

6. Geyer JR, Sposto R, Jenings M, Boyett JM, Axtell RA, et al. (2005) Multiagent chemotherapy and deferred radiotherapy in infants with malignant brain tumors: A report from the Children's Cancer Group. J Clin Oncol 23(30): 7621-7631.

7. Pomeroy SL, Tamayo P, Gaasenbeek M, Sturla LM, Angelo M, et al. (2002) Prediction of central nervous system embryonal tumour outcome based on gene expression. Nature 415(6870): 436-442.

8. McNeil DE, Cote TR, Clegg L, Rorke BL (2002) Incidence and trends in pediatric malignancies medulloblastoma/primitive neuroectodermal tumor: A SEER update. surveillance epidemiology and end results. Med Pediatr Oncol 39(3): 190-194.
9. Giangaspero F, Wellek S, Masuoka J, Gessi M, Kleihues P, et al. (2006) Stratification of medulloblastoma on the basis of histopathological grading. Acta Neuropathol 112(1): 5-12.

10. Rutkowski S, Gerber NU, Hoff KV, Gnekow A, Bode U, et al. (2009) Treatment of early childhood medulloblastoma by postoperative chemotherapy and deferred radiotherapy. Neuro Oncol 11(2): 201-210.

11. Sure U, Berghorn WJ, Wakabayashi T, Yoshida J, Sugita K, et al. (1995) Staging, scoring and grading of medulloblastoma. A postoperative prognosis predicting system based on the cases of a single institute. Acta Neurochir (Wien) 132(1-3): 59-65.

12. Packer RJ, Siegel KR, Sutton LN, Evans AE, Angio GD, et al. (1988) Efficacy of adjuvant chemotherapy for patients with poor-risk medulloblastoma: A preliminary report. Ann Neurol 24(4): 503-508. 